\title{
Influence of the Y Chromosome on Gonadal Differentiation: Asymmetrical Gonads in an XO/XY Mosaic*
}

\author{
PIERRE E. FERRIER $†$ and VINCENT C. KELLEY \\ From the F. Fudson Research Unit, Children's Orthopedic Hospital and Medical Center, and the Division of \\ Endocrinology and Metabolism, Department of Pediatrics, University of Washington, Seattle, U.S.A.
}

The $\mathrm{Y}$ chromosome has a strong masculinizing influence on the gonadal differentiation of the human embryo. Subjects with XXY, XXXY, and XXXXY sex chromosome constitutions invariably have male gonads, demonstrating that the influence exerted by the $\mathrm{Y}$ chromosome is not easily reversed. Testicular differentiation occasionally occurs in patients with an apparently pure XX sex chromosome complement (De la Chapelle, Hortling, Niemi, and Wennström, 1964; Hungerford, Donnelly, and Nowell, 1964; Cleveland and Chang, 1965). On the other hand, complete absence of testicular tissue has been observed in patients with an apparently uniform XY constitution ('pure gonadal dysgenesis') (Harnden and Stewart, 1959; Sohval, 1965). Such exceptions can be explained theoretically in several ways. One of the proposed hypotheses (Fraccaro, Taylor, Bodian, and Newns, 1962; Brøgger and Aagenaes, 1965) has been that partial or localized mosaicism accounts for the apparently paradoxical situation. It is postulated that this mosaicism may still be present in the organism but may be difficult to detect, or that the significant cell population (i.e. XY and XO cells) which existed at the critical time of gonadal differentiation has disappeared since then.

The present report brings additional support to the theory of mosaicism and stresses the point that in some circumstances even a small degree of mosaicism may be meaningful.

Received May 8, 1967.

* This study was supported by a U.S. Public Health Service Training Grant in Pediatric Endocrinology and Metabolic Diseases by a Research Grant from the National Institute of Child Health and Human Development, U.S. Public Health Service, and by a Research Career Development Award (P.E.F.) from the same Institute.

† Address: Department of Pediatrics, University of Washington,

\section{Case Report}

This $4 \frac{1}{2}$-month-old infant was referred to the University of Washington Medical Center because of ambiguity of the external genitalia. $\mathrm{He}$ was the product of the first pregnancy of an 18-year-old mother. Birth occurred at the end of the eighth month of gestation and the weight was $1400 \mathrm{~g}$. (2 lb. $13 \mathrm{oz}$.). Hypertrophy of the phallus with posterior labial fusion was noted at birth. A buccal smear at 10 days and again at 2 weeks of age demonstrated a negative chromatin pattern. Except for a left inguinal hernia noted at 1 month of age there was no other complication during the first weeks of life, and the weight gain was satisfactory: by 3 months, the weight was $4.6 \mathrm{~kg}$. ( $9 \mathrm{lb}$. $4 \mathrm{oz}$.) with a length of $51 \mathrm{~cm}$. (20 in.). A cystourethrogram performed at 5 weeks showed a normal bladder with an unusually long urethra.

On admission at $4 \frac{1}{2}$ months the baby weighed $5.54 \mathrm{~kg}$. and was $56 \mathrm{~cm}$. long. The state of nutrition, muscle tone, cry, and activity were excellent. No malformations other than those in the genital area were noted (Fig. 1). The external genitalia were characterized by a $2 \mathrm{~cm}$. phallus with a chordee and a urogenital sinus opening at the base (Fig. 2). On the left side there was an indirect inguinal hernia.

Laboratory Data. The serum electrolytes and urea nitrogen were within normal limits. The values of the urinary 17-ketosteroids, 17-hydroxycorticosteroids, and pregnanetriol were considered to be within the normal range for his age. Buccal smears showed a negative chromatin pattern on both sides.

Radiological studies. The bone age, estimated from multiple epiphysial centres, was consistent with the chronological age. An intravenous pyelogram demonstrated a good excretory capacity and good pyelocaliceal filling bilaterally. The kidneys were normal in size and position. A cine-urethrogram showed a slightly elongated and asymmetrical bladder, situated higher in the pelvis than usual. The urethra was longer and had a more posterior direction than usual. There was no filling of para-urethral structures or vagina, and no ureteral reflux. 


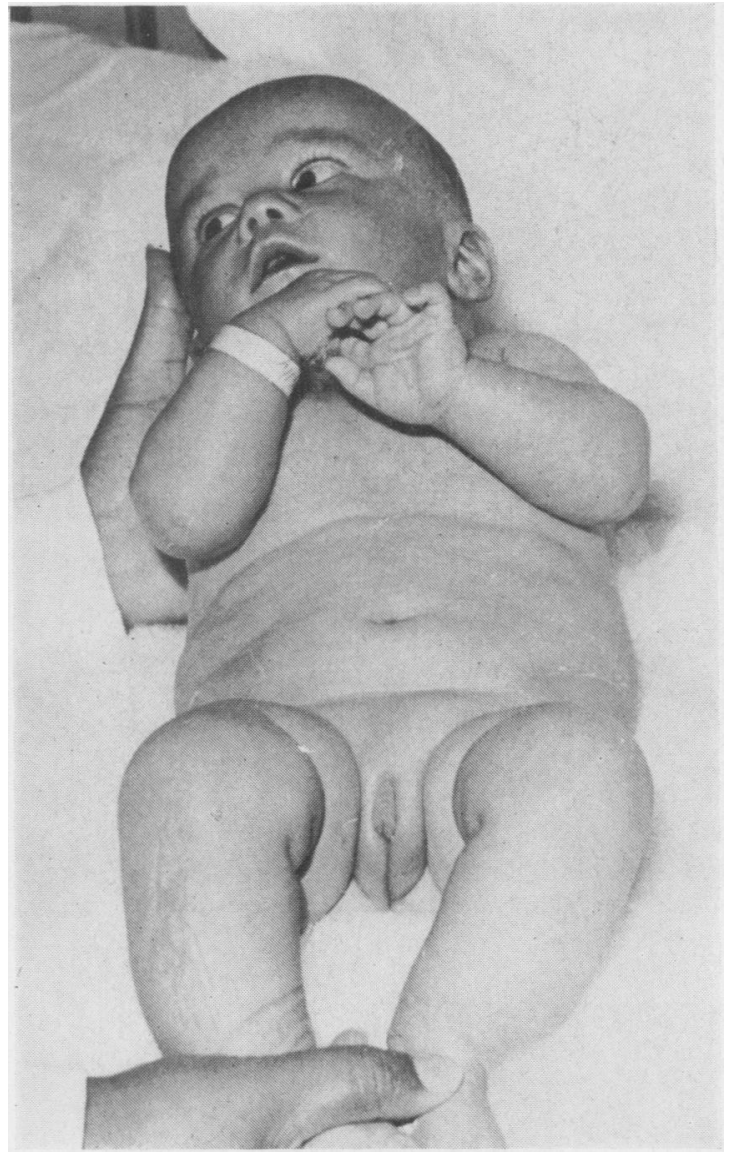

FIG. 1. The patient at $4 !$ months.

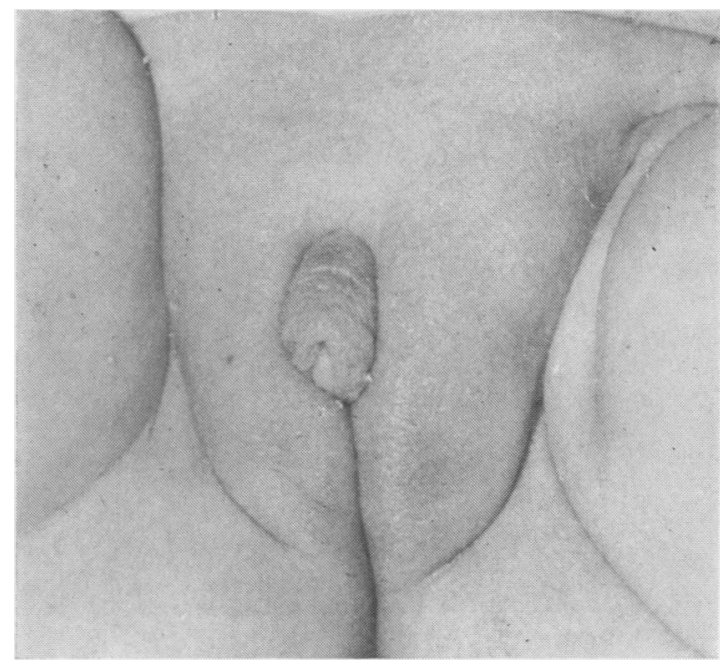

FIG. 2. External genitalia of the patient at $4 \frac{1}{2}$ months.
A laparotomy was performed at the age of 5 months and revealed a bicornuate uterus, well-developed fimbriated fallopian tubes on both sides, a spherical left gonad $1 \mathrm{~cm}$. in diameter and a right gonad $0.5 \mathrm{~cm}$. in diameter. Both gonads appeared the same, and they were symmetrically located in the usual position of ovaries. The left inguinal hernia contained only fatty tissue and no gonad. A small vagina was noted, with an infantile cervix. The urethra was female in appearance. A cystoscopy performed at the end of the procedure showed a normal bladder with ureteral orifices in the usual position. The uterus was left in situ and both gonads were removed, testicular tissue only having been identified by frozen sections. Subsequently both gonads were systematically examined.* 42 step sections of paraffin-embedded tissue were cut at $5 \mu$ and alternately stained with haematoxylin-eosin and Gomori's trichrome stains.

Histologically the left gonad was a primordial testis and the right gonad was partly testis and partly ovarian type stroma. The left gonad (Fig. 3) showed multiple immature seminiferous tubules which were lined by two types of cells morphologically recognized as Sertoli cells and primary spermatogonia. There was no evidence of differentiated Leydig cells. The rete testis and ductus deferens were included in the biopsy. No ovarian tissue could be found. A thick collagenous connective tissue layer immediately subjacent to the serosal cells was interpreted to represent a tunica albuginea.

The right gonad had a similar appearance, except that one end of the gonad assumed the typical structure of ovarian stroma with interdigitating fibrous stroma tissue (Fig. 4). No primary oogonia could be identified. In this region testicular type of tunica albuginea was not formed and ovarian cortical type of architecture extended to the surface. Cuboidal ovarian epithelium was not seen. Nests and cords of epithelial cells were seen in the stroma of this region but a population of ova could not be identified. An occasional cell in these nests was larger than the others and had a more vesicular cytoplasm but these cells were not surrounded by an orderly layer of follicle cells.

Cytogenetic Findings. The karyotype findings in peripheral blood leucocytes, skin of the right forearm, and of the left abdomen, and tissues from both gonads are summarized in the Table. A mosaicism of the 45, $\mathrm{XO} / 46$, XY type was present in the peripheral blood leucocytes. The same type of mosaicism of the sex chromosomes could be demonstrated in the skin of the right forearm (Fig. 5 and 6), in the skin of the left side of the abdomen, and in the right gonad. In all cultures the XO cells outnumbered the XY cells, particularly in cultures from the two skin sites and from the right gonad. The left gonad appeared to contain cells of the 45, XO type only.

* The histopathology of this case was studied by Dr. N. Karle Mottet, professor of Pathology and Director of Pathology, University Hospital. 


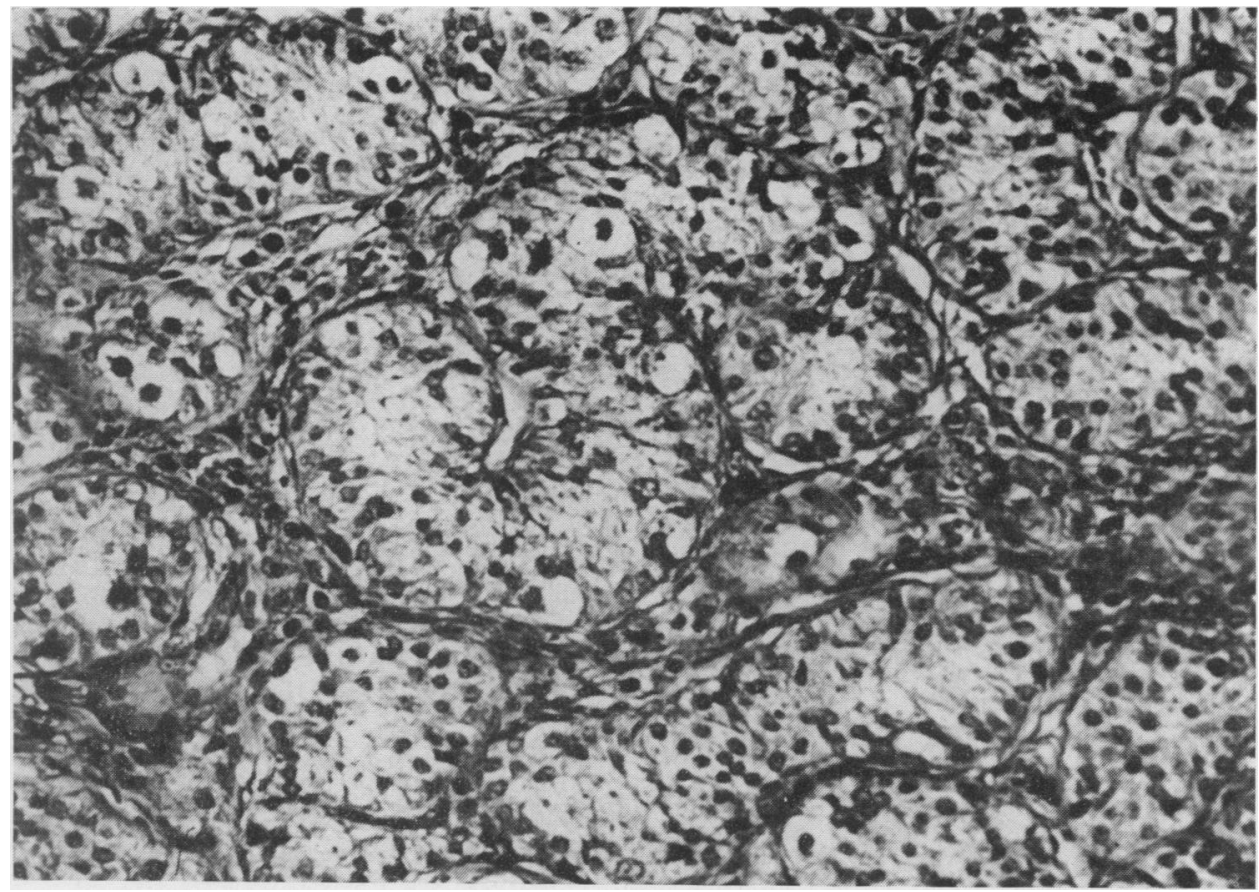

Fig. 3. Left gonad. Seminiferous tubule structure. (H. and E. $\times 350$.) XO cells only were recovered in cultures from this organ.

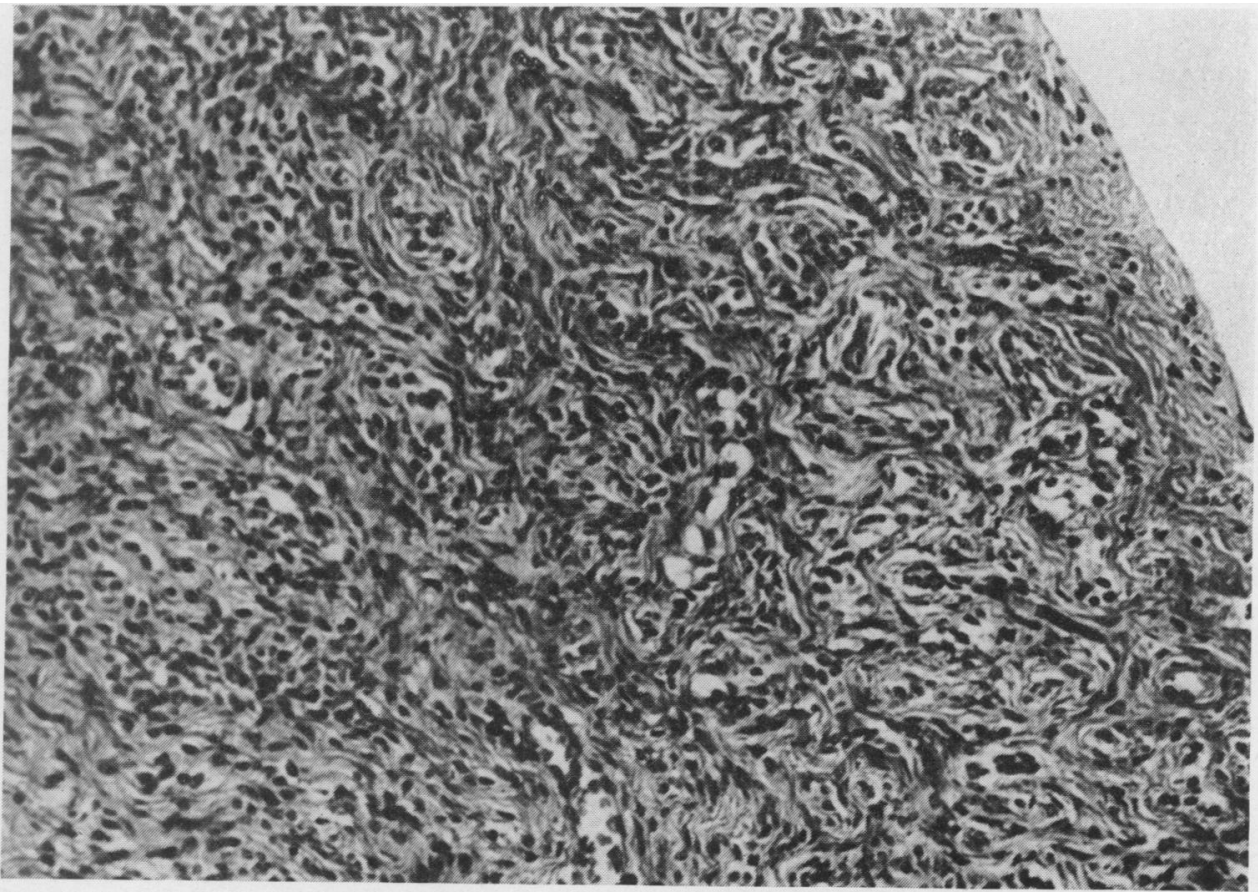
Fig. 4. Right gonad. Portion of the gonad with ovarian stroma type of architecture. Absence of germ cells is conspicuous. (H.
and E. $\times 350$.) 


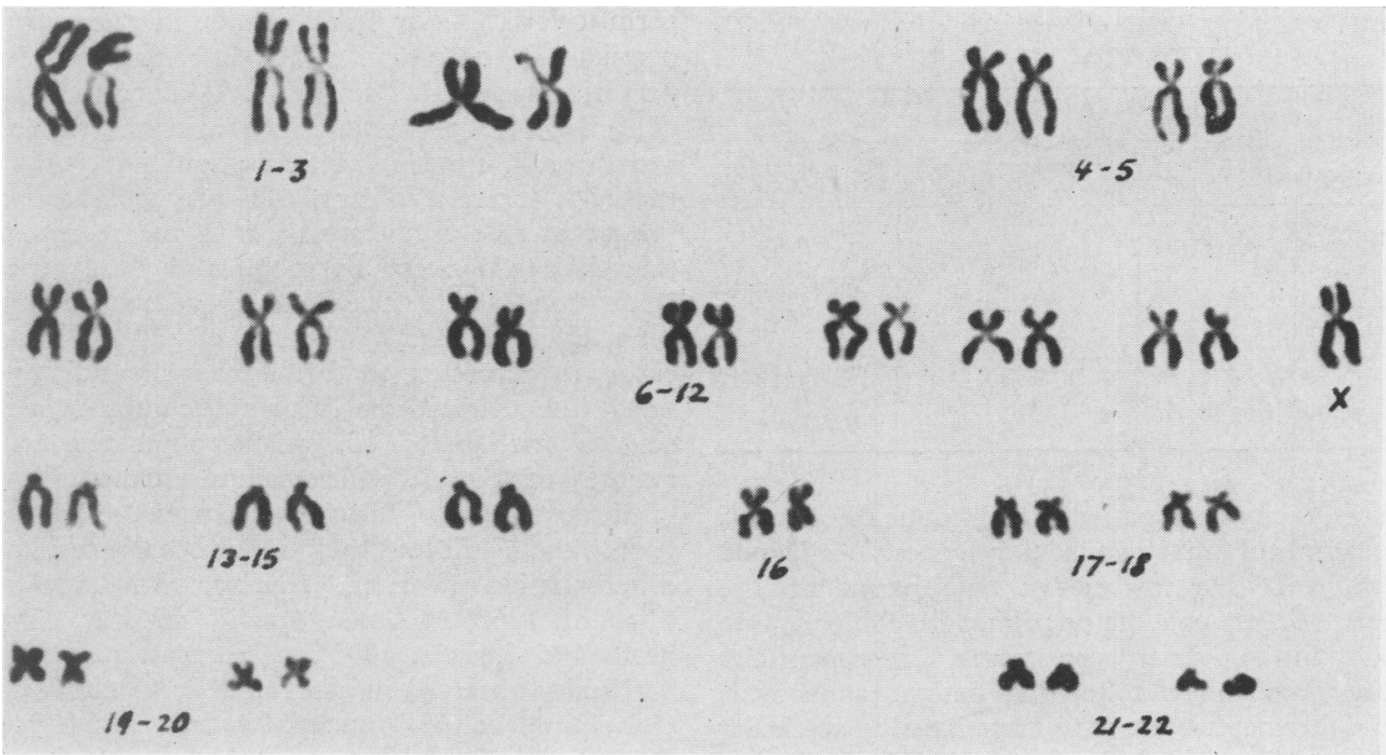

Fig. 5. Chromosomes of a 45 , XO cell from the right gonad.
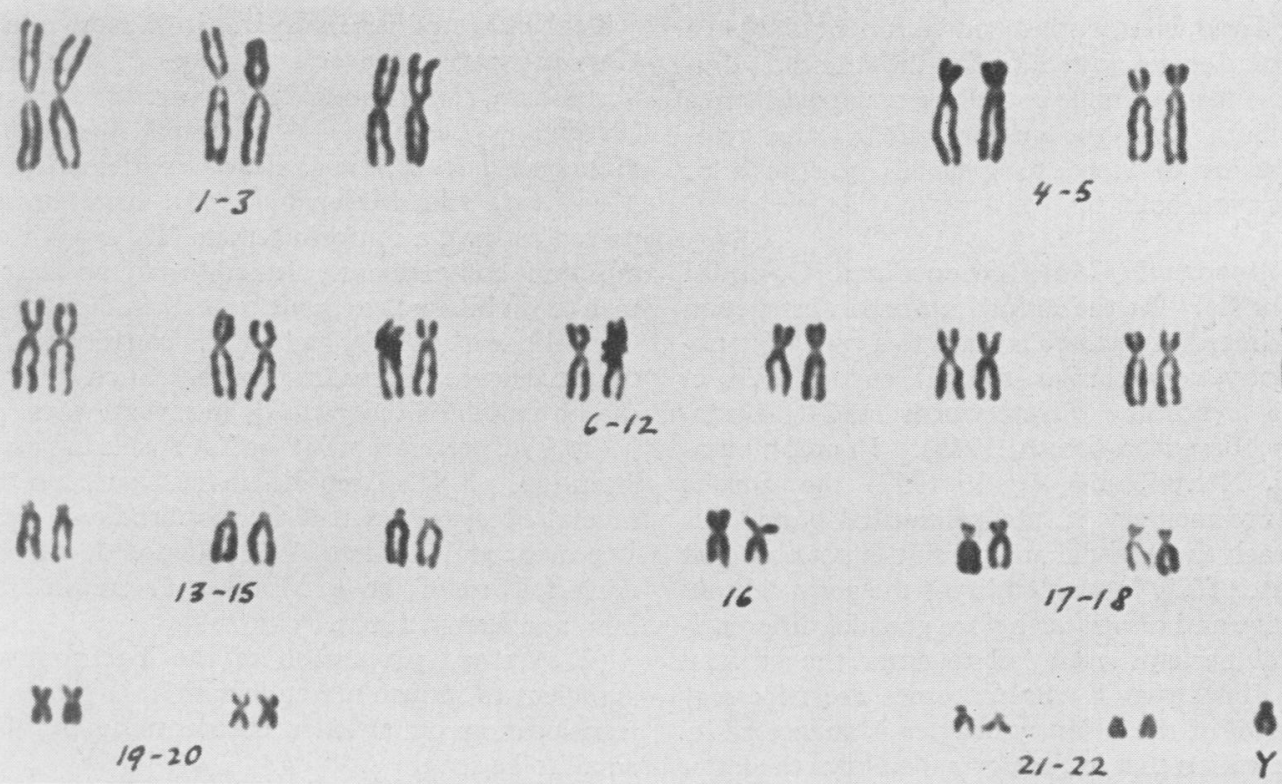

16

Fig. 6. Chromosomes of a 46, XY cell from the skin. Autoradiographic studies of similar cells were carried out and the chromosome labelling pattern supported the interpretation of an XY sex chromosome complement.

\section{Discussion}

Asymmetrical Gonadal Differentiation. In 1963 Sohval proposed the term 'mixed gonadal dysgenesis' to identify a condition characterized by asymmetrical abdominal gonads (a gonad streak akin to that found in Turner's syndrome on one side and $5+$ an abnormal testis on the opposite side). These patients usually present with some degree of ambiguity of the external genitalia. The majority of them have been found to have a mosaic sex chromosome complement of the XO/XY type (Zourlas and Jones, 1965). Since he had testicular tissue in both 
TABLE

KARYOTYPE FINDINGS

\begin{tabular}{|c|c|c|c|c|c|c|c|}
\hline \multirow[t]{2}{*}{ Tissue } & \multirow{2}{*}{$\begin{array}{c}\text { No. of } \\
\text { Cells } \\
\text { Counted }\end{array}$} & \multicolumn{3}{|c|}{ Chromosome No. } & \multicolumn{3}{|c|}{ Karyotypes } \\
\hline & & 45 & 46 & Others & $45-\mathrm{XO}$ & $46-X Y$ & Others \\
\hline \multirow{5}{*}{$\begin{array}{l}\text { Peripheral } \\
\text { leucocytes } \\
\text { Skin right } \\
\text { forearm } \\
\text { Skin left } \\
\text { abdomen } \\
\text { Right } \\
\text { gonad } \\
\text { Left } \\
\text { gonad }\end{array}$} & 43 & 31 & 12 & 0 & 3 & 7 & 0 \\
\hline & 73 & 68 & 4 & 1 & 9 & 2 & 1 \\
\hline & 36 & 35 & 1 & $\mathbf{0}$ & 6 & 1 & 0 \\
\hline & 72 & 69 & 1 & 2 & 11 & 1 & 0 \\
\hline & 72 & 70 & 0 & 2 & 8 & 0 & 1 \\
\hline
\end{tabular}

gonads, the present patient could not be classified as an example of 'mixed gonadal dysgenesis' as defined by Sohval. He was not a true hermaphrodite either, because oogonia or primordial follicles were lacking in the ovarian type stroma. It seems more appropriate to refer to this patient as a male pseudohermaphrodite with 'asymmetrical testicular differentiation', for lack of a better term. An abnormal testis with a thick capsule similar to the one reported here has been observed by Schlegel, Carneiro Leao, Neu, Farias, and Gardner (1966) in a phenotypic female with XO/XY mosaicism. Evidently this form of male pseudohermaphroditism is related, both from the anatomical and the cytogenetic point of view, to gonadal dysgenesis or Turner's syndrome.

Chromosomal Complement and Gonadal Ontogenesis. In the animal embryo destruction of the primordial germ cells leads to a type of gonadal atrophy very similar to that encountered in Turner's syndrome (Hemsworth and Jackson, 1963a, b; Ferguson-Smith, 1965). In amphibians (Witschi, Nelson, and Segal, 1957) the gonads remain rudimentary if the primordial germ cells fail to reach the gonadal anlage. It is possible that in the case of XO human embryos the germ cells do not survive and disappear before gonadal differentiation and perhaps even fail to enter the gonadal anlage. That two $\mathrm{X}$ chromosomes are necessary for survival of the primary oocytes is suggested by the observation that in the normal embryo the latter show no sex chromatin mass even after heterochromatinization (or inactivation) of the second $\mathrm{X}$ takes place in the other cells (Ohno and Makino, 1961 ; Ohno, Makino, Kaplan, and Kinosita, 1961). Therefore, it may be that oocytes with only one $\mathrm{X}$ chromosome are not viable in man, and subsequently the gonads of XO human female embryos remain in the form of fibrous 'streaks'. In the normal embryo, on the contrary, the presence of normal germ cells (XX or $\mathrm{XY}$ ) results in the normal ovarian (XX) or testicular (XY) differentiation of the primitive gonads. The germ cells allow the gonadal anlage to differentiate in accordance with the genetic make-up of its cellular population. If this theory is correct the germ cells play a limited but important role as inductors, with the reservation that their action can be modified by the genetic constitution of the cells of the gonadal anlage itself (of a different origin). Gonads of XO/XY mosaic embryos, according to this view, will undergo as much testicular differentiation as the number of $\mathrm{XY}$ cells allows. Parts of gonads populated by a majority of XO cells will remain in the neutral state of fibrous streaks. In other instances the XY cells predominate and lead to a predominantly testicular differentiation (Ferrier, Gartler, Waxman, and Shepard, 1962; Mellman, Klevit, Yakovac, Moorhead, and Saksela, 1963). The great phenotypic variability observed in cases of $\mathrm{XO} / \mathrm{XY}$ mosaicism (Job, Canlorbe, de Grouchy, Cendron, and Rossier, 1966; Jackson, Hoffman, and Makda, 1966) supports this theory, which is summarized in Fig. 7.

Testicular Differentiation in Absence of a $\mathbf{Y}$ Chromosome. Several instances of true hermaphroditism, well studied by multiple biopsies (Bregman, Bregman, Cushner, and Woods, 1963; Hungerford et al., 1964; Root, Eberlein, Briebart, Moorhead, and Mellman, 1964), have been reported to have a uniform female XX type of chromosome complement. In addition, at least one man (with bilateral atrophic testes), studied by De la Chapelle et al. (1964), had an XX constitution in all tissues cultured, including testes. Such exceptions can be explained theoretically in several ways.

(1) The presence of XY or XXY cells has escaped attention. $\mathrm{XX} / \mathrm{XY}$ mosaicism has been reported on several occasions in true hermaphrodites (Gartler, Waxman, and Giblett, 1962; Josso, de Grouchy, Auvert, Nezelof, Jayle, Moullec, Frézal, de Casaubon, and Lamy, 1965).

(2) A small proportion of the $Y$ chromosome, sufficient to induce masculinization, is present as a translocation on another chromosome but is too small to be seen.

(3) Some instances of sex reversal are due to the action of an autosomal gene whose effect is similar to that of the 'transformer gene' (Sturtevant, 1945) or the 'double-sex gene' (Hildreth, 1965) in drosophila.

(4) Sex reversal is sometimes due to the action of some (unknown) extragenetic, environmental factor.

It is believed that the present case offers some clues with regard to the role of the $\mathrm{Y}$ chromosome in intersex conditions. The left testis was consti- 


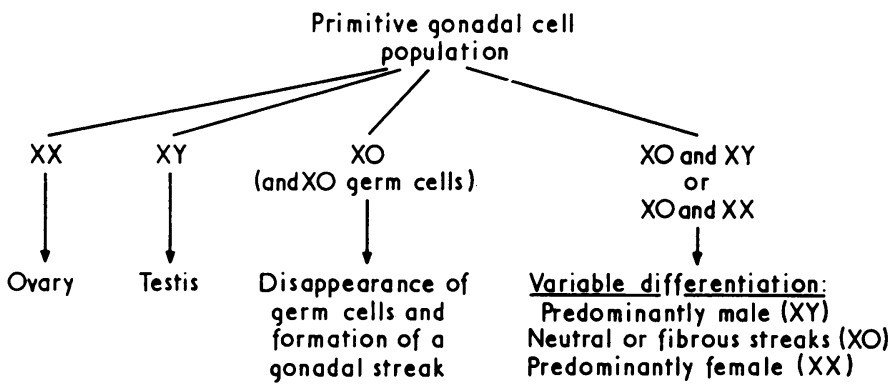

FIG. 7. Theory on the genetic basis of gonadal differentiation.

tuted (to the extent that cells recovered in tissue cultures are representative of the gonadal cell population in general) exclusively of XO cells. It is believed that $\mathrm{XY}$ cells must have been present also, but had either disappeared by 5 months of age or did not grow in culture, and that they accounted for the testicular structure of this gonad. This belief is sunported by the finding of a few XY cells in the right gonad (as well as in the skin and in the leucocytes). $\mathrm{XY}$ cells do not arise de novo in a population of XO cells, and they, therefore, must have been present at the time of gonadal differentiation. Their presence is thought to be significant with regard to the pre-eminent role of the $\mathrm{Y}$ chromosome in testicular differentiation.

\section{Summary}

A 5-month-old infant with asymmetrical gonadal differentiation (a testis on one side and a mixed gonad-testicular structure and ovarian type of stroma - on the opposite side) was found to be a sex chromosome mosaic of the XO/XY type. This sex chromosome mosaicism was present in the leucocytes, the skin of the right forearm and of the left abdomen, and in the right gonad. The left gonad, though entirely testicular in structure, produced only XO cells when cultured. The great majority of the cells obtained from the other tissues also were of the XO type. It is thought that the male differentiation of the gonads was due to the presence of $\mathrm{XY}$ cells in the embryonic anlage. It is felt that even a minor mosaicism including XY cells, as in the present case, is of significance with regard to gonadal differentiation and the pre-eminent role of the $\mathrm{Y}$ chromosome. This example demonstrates that karyotype analyses limited to tissue from a single source may be misleading with regard to the importance of the $\mathrm{Y}$ chromosome in testicular differentiation.
Our thanks are due to Professor N. Karle Mottet for the interpretation of the histological slides and for Fig. 3 and 4. The technical assistance of Mrs. Earlene Benefield and Mrs. Lucy Fueresz is gratefully acknowledged.

\section{REFRRENCES}

Bregman, R. U., Bregman, E. T., Cushner, G. B., and Woods, F. M. (1963). Chromosome analysis, nuclear sex, clinical and endocrine studies of a true hermaphrodite. $\mathcal{f}$. Urol. (Baltimore), 89, 475 .

Brøgger, A., and Aagenaes, O. (1965). The human Y chromosome and the etiology of true hermaphroditism. Hereditas (Lund), 53, 231 .

Cleveland, W. W., and Chang, G. C. H. (1965). Male pseudohermaphroditism with female chromosomal constitution. Pediatrics, 36, 892.

De la Chapelle, A., Hortling, H., Niemi, M., and Wennström, J. (1964). XX sex chromosomes in a human male. First case. Acta med. scand., Suppl. 412, 25.

Ferguson-Smith, M.A. (1965). Karyotype-phenotype correlations in gonadal dysgenesis and their bearing on the pathogenesis of malformations. f. med. Genet., 2, 142.

Ferrier, P. E., Gartler, S. M., Waxman, S. H., and Shepard, T. H. (1962). Abnormal sexual development associated with sex chromosome mosaicism. Pediatrics, 29, 703.

Fraccaro, M., Taylor, A. I., Bodian, M., and Newns, G. H. (1962). A human intersex ('true hermaphrodite') with $\mathrm{XX} / \mathrm{XXY} / \mathrm{XXYYY}$ sex chromosomes. Cytogenetics, 1, 104.

Gartler, S. M., Waxman, S. H., and Giblett, E. (1962). An XX/XY human hermaphrodite resulting from double fertilization. Proc. nat. Acad. Sci. (Wash.), 48, 332.

Harnden, D. G., and Stewart, J. S. S. (1959). The chromosomes in a case of pure gonadal dysgenesis. Brit. med. $\mathcal{F}_{\text {., }}, 1285$.

Hemsworth, B. N., and Jackson, H. (1963a). Effect of Busulphan on the developing gonad of the male rat. $\mathcal{F}$. Reprod. Fertil., $5,187$. , and - (1963b). Effect of Busulphan on the developing ovary in the rat. ibid., 6, 229.

Hildreth, P. E. (1965). Doublesex, a recessive gene that transforms both males and females of Drosophila into intersexes. Genetics, $51,659$.

Hungerford, D. A., Donnelly, A. J., and Nowell, P. C. (1964). The chromosome constitution of a human phenotypic intersex: reconfirmation of a 46-chromosome, XX, apparently non-mosaic 'true hermaphrodite'. Hereditas (Lund), 52, 379.

Jackson, W. P. U., Hoffman, M., and Makda, H. (1966). The $45 \mathrm{XO} / 46 \mathrm{XY}$ mosaic intersex syndrome. F. med. Genet., 3, 23.

Job, J. C., Canlorbe, P., de Grouchy, J., Cendron, J., and Rossier, A. (1966). Mosaiques cellulaires XO/XY. Arch. franc. Pédiat., 23, 297.

Josso, N., de Grouchy, J., Auvert, J., Nezelof, C., Jayle, M. F., Moullec, J., Frézal, J., de Casaubon, A., and Lamy, M. (1965). True hermaphroditism with $X X / X Y$ mosaicism, probably due to double fertilization of the ovum. F. clin. Endocr., 25, 114 . 
Mellman, W. J., Klevit, H. D., Yakovac, W. C., Moorhead, P. S., and Saksela, E. S. (1963). XO/XY chromosome mosaicism. ibid., 23, 1090.

Ohno, S., and Makino, S. (1961). The single-X nature of sexchromatin in man. Lancet, $1,78$.

- - Kaplan, W. D., and Kinosita, R. (1961). Female germ cells of man. Exp. Cell Res., 24, 106.

Root, A. W., Eberlein, W. R., Briebart, S., Moorhead, P. S., and Mellman, W. J. (1964). Chromosomal analysis of multiple tissues from a true hermaphrodite. F. clin. Endocr., 24, 467.

Schlegel, R. J., Carneiro Leao, J., Neu, R. L., Farias, E., and Gardner, L. I. (1966). Testicular XO/XY mosaicism in a phenotypic female with XY sex chromosome in other tissues. ibid., 26, 847.
Sohval, A. R. (1963). 'Mixed' gonadal dysgenesis: a variety of hermaphroditism. Amer. F. hum. Genet., 15, 155.

(1965). The syndrome of pure gonadal dysgenesis. Amer. f. Med., 38, 615.

Sturtevant, A. H. (1945). A gene in Drosophila melanogaster that transforms females into males. Genetics, 30, 297.

Witschi, E., Nelson, W. O., and Segal, S. J. (1957). Genetic, developmental and hormonal aspect of gonadal dysgenesis and sex inversion in man. f. clin. Endocr., 17, 737.

Zourlas, P. A., and Jones, H. W. (1965). Clinical, histologic, and cytogenetic findings in male hermaphroditism. III. Male hermaphrodites with asymmetrical gonadal differentiation (mixed gonadal dysgenesis). Obstet. and Gynec., 26, 48. 